\title{
Moral Perfection and the Demand for Human Enhancement ${ }^{1}$
}

\author{
Adriana Warmbier (Jagiellonian University, Cracow)
}

\begin{abstract}
Again, the case of the arts and that of the virtues are not similar; for the products of the arts have their goodness in themselves, so that it is enough that they should have a certain character, but if the acts that are in accordance with the virtues have themselves a certain character it does not follow that they are done justly or temperately. The agent also must be in a certain condition when he does them; in the first place he must have knowledge, secondly he must choose the acts, and choose them for their own sakes, and thirdly his action must proceed from a firm and unchangeable character. These are not reckoned in as conditions of the possession of the arts, except the bare knowledge; but as a condition of the possession of the virtues knowledge has little or no weight, while the other conditions count not for a little but for everything, i.e. the very conditions which result from often doing just and temperate acts.
\end{abstract}

Aristotle, The Nicomachean Ethics (Aristotle 2009, 1105b)

\section{Naturalism, Human Agency, and the Idea of Moral Enhancement}

Recent developments in neuroscience, genetics, and psychology have significantly increased the range of potential uses of biomedical technologies. What used to be implemented simply to maintain or restore health may now allow us to expand human capacities above normal levels. The growth of knowledge provides people with means which may have an important influence on their standard of living. The very attempt to improve one's quality of life does not seem in itself to raise a moral dilemma. After all, as soon as we are fully conscious we start to pose the question: what do I ought to do to make my life meaningful or fulfilling, and what do I owe to others? We discover in ourselves both the desire for personal development, including moral attitudes, and the fact that we are subject to norms and moral judgment. ${ }^{2}$ Already Plato and Aristotle believed that striving for perfection is an integral part of growing up. Being human entails learning virtue, which they thought to be a kind of excellence. We may all agree that this tendency is

1 The writing of this article was funded by the Polish National Science Centre NCN (2012/07/D/HS1/01099).

2 On the active and passive aspects of our nature in terms of morality see: Korsgaard (1989, 101-132). 
still present, whether we assume it derives from our nature or not. We constantly deliberate on ways in which we could be better, more perfect, and far different fom what in fact we are (Korsgaard 2013). ${ }^{3}$ Yet since the ancients our approach to values and understanding of morality itself has changed significantly.

There are many reasons for this transformation. The pivotal one is, as Bernard Williams puts it, "that contemporary views about morality itself leave an unclarity about what qualities of mind or character are particularly called upon in constructive moral thought (indeed, in some accounts of morality it is not even clear that there can be such a thing as constructive moral thought)" (Williams 1996, XVIII; see also: Williams 2006). With regard to this statement, there are two things to be mentioned here at the outset. First, leaving aside those accounts of morality in which the possibility of constructive consideration of the moral kind is discarded, we may indicate two main tendencies in contemporary takes on what morality is. Generally speaking, one evolved from Aristotelian anthropology or Kantian ethics, and the other is based on reductionism of various kinds. ${ }^{4}$

Second, whichever tendency we choose to pursue in our investigation into morality, and whichever sense of this concept, broad or narrow sense, we choose to adopt, we cannot evade the question of what it is to be a human agent, or a self. The themes of morality and agency (selfhood) are inextricably intertwined (see: Taylor 1994). But just as there is more than one understanding of the concept of morality, so will there be miscellaneous depictions and strands of the notion of human agency.

In this article I shall not attempt to discuss all the philosophical accounts of a person or self. What I want to bring out and examine are the conditions of possibility of moral agency, in other words, the possibility of self-understanding, acting subjects attributing responsible authorship for their actions to themselves. These two issues, the acting subject and the attribution of authorship, are integrally related. In exploring this theme I shall turn to the idea of human enhancement, which is one of the major topics of contemporary debate in practical ethics. As this is a vast and complex field, I shall concentrate only on one important aspect, namely, moral enhancement.

If we are to discuss the idea of moral enhancement, we must start by examining two substantial issues ${ }^{5}$. The first one refers to the assumption

\footnotetext{
${ }^{3}$ In particular see the Prologue in Excellence and Obligation: A Very Concise History of Western Metaphysics 387 BC to 1887 AD.

${ }^{4}$ The effects of the first tendency may be called an attempt to plot a course between the two theories by showing the insufficiency of each and by bringing out their similarities.

${ }^{5}$ When considering moral enhancement, John Harris begins with these questions: "what is moral enhancement and what does it have to do with ethical knowledge, if there is such a thing, or with ethical expertise; and what do all of these have to do with knowledge of ethics or morality?" (Harris 2011,104).
} 
underlying this idea. According to the account of moral enhancement given by Thomas Douglas, who suggests that the enhanced person is expected to have morally better motives than she had before the alteration (Douglas 2008), one may ask what would make us think that biomedical interventions might result in having "morally better motives" when morality is regarded as being based on set of beliefs, moral norms, and rational considerations. In other words, it derives from the "capacity for reflective self-evaluation" (see: Frankfurt 1971, 7). The second issue is that of, what acting morally actually involves? My claim is that the idea of moral enhancement, which some may regard as very promising (in particular in terms of improving moral decision-making processes) is founded on a certain picture of the human being. This picture derives from a reductionist research programme ${ }^{6}$ that refers to a very narrow form of naturalism. An accurate depiction of this sort of naturalism can be found in John McDowell's Mind and World. The author states that this naturalism "equates disclosing how something fits into nature with placing it in the realm of law" (McDowell 1996, 88). Those who consider moral enhancement as an alternative means of improving our moral capacities embrace naturalism in its narrow form, with its reductionist tendency.

As I mentioned above, this sort of naturalism has significant consequences. It is more than just one of the views about the language of science. It ramifies into the very comprehension of human agency (see: Taylor 1985). A number of various and influential accounts have been put forth explaining the nature of moral enhancement and the reasons for seeking it (see: Douglas 2008; Persson \& Savulescu 2012; Daniels 2013, Walker 2009). In what follows, I would like to show that the heart of the controversy that pertains to the idea of moral enhancement lies in the issue which is often sidestepped or just not properly introduced by the proponents of biomedical enhancement, namely the complex character of the basis of moral decision making. We may agree that this complexity consists in the determining and non-determining factors which take part in the process of evaluating reasons that are taken into account in our moral choices.

The idea of moral enhancement should provide us with a conception of what exactly is claimed to be enhanced and what the consequences of it are. I shall focus my attention on the realm of moral decisions making. First, I will support the thesis that genetic endowments does not play a dominant role in the process of making moral choices. Second, in answering the questions of what are the conditions of self-understanding and what it is to be an autonomous and responsible agent, I shall argue that the idea of moral enhancement fails to justify the claims that enhancing the "biological" factor that plays a part in the process of making moral choices, whether through

${ }^{6}$ Of course, there is not one reductionist research programme. One may point out various forms of reductionism, depending on what is said to be reducible to what. For a brief account (see: Haack 2014). 
biomedical or genetic interventions, will increase the probability of having "morally better future motives".

\section{Autonomy, Rationality, and Freedom of the Will}

"For reason recognizes as its highest practical function the establishment of a good will, whereby in the attainment of this end reason is capable only of its own kind of satisfaction, viz., that of fulfilling a purpose which is in turn determined only by reason, even though such fulfilment were often to interfere with the purposes of inclination."

I. Kant, Grounding for the Metaphysics of Morals $(1993,9)$

Tadeusz Kotarbiński claimed that human autonomy involves two fundamental concepts: rationality and freedom of the will. Moreover, he suggested, that these two notions are related, one cannot go without the other. A similar conviction may be found in the ancient thought, where the ideas of moral action and reflection were regarded as inextricably connected. In line with this kind of thinking, let me invoke the meaning of the term "rationality". It is usually taken in two senses, namely "purposefulness" and "meaningfulness". The concept of rationality is confined to the framework of discursive cognition. "A rational demand is a demand which has a meaning, and this, in turn, signifies that the demand has been well thought over, justified, andagain! - properly subordinated to the intended goal" (Stróżewski 2013, 282283). This is what Aristotle means when he states that a normal, mature human being is rational. The realm of rationality entails an agent equipped with a responsiveness to reasons. If we lacked this capacity for responsiveness we would not be able to refer to and take into consideration the whole framework of our intentions, motives, and inclinations. This is precisely what is essential in the concept of freedom of free will: being capable of "reflective self-evaluation". In other words, the primary meaning of the notion of freedom is not "to be free to choose", but the very ability to be critically aware both of the difference between what Kant calls the "purposes of reason" and the "purposes of inclination" and of he experience of being capable of directing one's own intention.

Since moral consideration involves the concept of agency, I shall turn again to Aristotle. He puts forward an idea of what it is to be a free agent by introducing the distinction between voluntary and involuntary actions. Let me take a closer look at this distinction now, as it may shed light on some important problems concerning the question of self-understanding, acting subjects. In The Nicomachean Ethics Aristotle asserts:

Since that which is done by force or by reason of ignorance is involuntary, the voluntary would seem to be that of which the moving principle is in the agent himself, he being aware of the 
particular circumstances of the action ... We deliberate about things that are in our power and can be done; and these are in fact what is left (Aristotle 2009, 1111a-1112b).

It is to voluntary action that practical intellect directs itself. This kind of action involves two important factors, namely "intention" (choice) and "deliberation", which complete themselves within the sphere of conscious subjective experience. For the "act of intention", Aristotle uses the term proairesis and for the "act of deliberation", he uses the term bouleusis (see: Aristotle 2009, 1111b,4-1112a,16; 1112a,17-1113a,14). Considering these two factors, the essential point is their mutual dependence. Aristotle argues that when one deliberates and decides as a result of deliberation, then one desires (has the intention of doing certain things) in accord with this deliberation. The very thing they desire after deliberation is proaireton. Thus deliberation completes itself by the act of proairesis (intention). The proaireton is one of the things within our power which is desired after deliberation. ${ }^{7}$

What Aristotle emphasizes here is that deliberation fulfils itself only in the act of proairesis. In explaining the meaning of proairesis he presents us with the following phrases: "desiderative reason" or "ratiocinative desire" (Aristotle 2009, 1139b,4). Thus the act of choosing-proairesis-may be effected only by involving both reason and desire with a view to an end. "Deliberate desire" introduces into the concept of proairesis the appetitive moment. There can be no question that in the effort to capture the significance of the act of choice Aristotle focuses our attention on the unified and integrated action of the two sorts of abilities. As Grimaldi comments: "Aristotle leads up to this statement by demonstrating that the appetitive element must enter into proairesis since choice has its origin in both desire and reason, for reason by itself will not cause action" (Grimaldi 1972, 26).

When we have reached a judgement as a result of deliberation, we desire in accordance with our deliberation (Aristotle 2009, 1113a). ${ }^{8}$

Thus the Aristotelian model of action consists in a dialectical dependence between deliberation and desire. Our decisions, especially moral decisions, are based upon thoughts that we hold as prior. What is vital in these ancient grasp of the concept of "deliberate desire" and what pushes me towards Aristotle's model of action, is that it demonstrates the condition sine qua non of morality. Not only does it emphasizes the complexity of conscious actions, which are understood to be the result of a "chain of intentions and considerations that weigh up ends and alternative means in light of

${ }^{7}$ I am relying on the commentary on Aristotle written by Grimaldi $(1972,26)$.

8 Grimaldi translates these phrases as "desireful reason" and "reasonable desire" (Grimaldi 1972, 26). 
opportunities, resources, and obstacles" (Habermas 2008, 155), but in the first place it addresses the active aspect of our nature, namely, it brings out the agency of persons, the reflective self.

The structure of the reflective will, which I shall also call the axiological structure of agency, is by its nature determined by its inner relation to values. ${ }^{9}$ Due to this, I say that it is only within the reflective will that freedom may be claimed to implement itself. The internal connection to reasons and norms turns our act of choosing into a free action, and hence constitutes morality. The main task of the axiological structure of agency consists in its teleological character. Its most important determining factor is the attitude of the agent, towards the choice of values and their realisation within oneself (Stróżewski 2013, 270; see also Habermas' critique of Libets experiments in: Habermas 2008, 154-166). The approach to reasons, norms and values is of a specific kind. Let me invoke its detailed description which Władysław Stróżewski gives in his text Axiological Structure of Human Being.

The axiological structure of agency is: 1 . radically individualistic; 2 . It comprises various types of values (not only moral ones); 3 . It is hierarchical; 4. It comprises both positive and negative values; 5 . It contains both deterministic and indeterministic factors; 6. It is dynamic; 7. It is dialectical; 8. It is made up of both actually existing and potential values, as well as of both realized and merely postulated values; 9 . It may be characterized by both the harmony and disharmony of its component elements; 10. It is teleological in character: its most significant "determining" factor is the agent's attitude towards values (see: Stróżewski 2013,258). What I am claiming here is that an adequate explanation of moral action must take into account the aforementioned broad contexts of reflectiveness. Keeping in mind this essential characteristic of the axiological structure of agency I shall now discuss the idea of moral enhancement.

Thomas Douglas presented the following accounts of moral enhancement:

There are various ways in which we could understand the suggestion that we morally enhance ourselves. To name a few, we could take it as a suggestion that we make ourselves more virtuous, more praiseworthy, more capable of moral responsibility, or that we make ourselves act or behave more morally. But I will understand it in none of these ways. Rather, I will take it as a suggestion that we cause ourselves to have morally better motives ... I understand motives to be the psychological-mental or neural-states or processes that will, given the absence of opposing motives, cause a person to act (Douglas 2008, 229).

\footnotetext{
9 I borrow this phrase from Władysław Stróżewski who uses it precisely as "the axiological structure of man" (or of a human being). See: Stróżewski (2013, 257-271).
} 
The radical version of this account is offered by Ingmar Persson and Julian Savulescu who claim that cognitive improvement should be accompanied by an extensive moral enhancement of humankind. Thus we need to explore the possibility of using the "science of morality" to develop and apply means of enhancing our "moral dispositions". Of course, they acknowledge the possibility of moral enhancement through self-education and social reform, but since this does not seem to be effective, they focus on what they call "moral bioenhancement", by which they mean the modification of individuals' moral psychology through the application of pharmacology, neuroscience, and genetic selection or modification.

At the very least, the perils of cognitive enhancement require a vigorous research program on understanding the biological underpinnings of moral behaviour. As Hawking quipped, our future may depend on making ourselves wiser and less aggressive. If safe moral enhancements are ever developed, there are strong reasons to believe that their use should be obligatory, like education or fluoride in the water, since those who should take them are least likely to be inclined to use them. That is, safe, effective moral enhancement would be compulsory (Persson \& Savulescu 2008, 174).

In another text Savulescu and Persson argue:

To be morally enhanced is to have those dispositions which make it more likely that one will arrive at the correct judgment of what it is right to do and more likely to act on that judgment (Savulescu \& Persson 2012, 403).

Mark Walker puts forward the Genetic Virtue Project which proposes to discover and enhance morality using biotechnology genetic correlates of virtuous behavior. His arguments rely on the assumption that virtues have biological correlates.

The companion in innocence point applies to the idea of promoting virtue: much of our (pre-theoretic) ethical practice assumes that virtues are important. An enormous amount of energy is spent attempting to socialize people into being virtuous, as in teaching children to be truthful, just, and caring. If the "Genetic Virtue Project" is wrong in attempting to promote virtue as a means of making people morally better, then much current socialization and education is mistaken as well (Walker 2009, 35).

The main problems that spring from such an approach are as follows:

1. The transhumanistic standpoint addresses only one side of our nature, namely its passive aspect, which consists in the fact that we encounter the existence of deterministic factors such as goals of inclinations, various emotions, or feelings. But these factors, even though they contribute to moral action, do not determine normativity itself. Since normativity derives from 
reflection, which in turn reveals the individual's relation towards reasons and values, the transhumanistic premises lead to substantial disagreement in viewing morality. They tend to follow the Darwinian approach, according to which moral insight is something that one regards as happening to them, something that is an object of one's experience, whereas moral norms do not, in fact, originate from our inclinations or psychical dispositions.10 That is why the idea of moral enhancement pertains only to the outer (mainly biomedical) means of controlling and influencing "moral dispositions" and behavior. I endorse Harris's remark that there is mischief in the meaning of the words "safe and effective" moral enhancement (see: Harris 2011, 106). One may wonder what is actually claimed here to ought to remain "safe and effective".

2. The aforementioned issue generates other difficulties. Since the proponents of biomedical enhancement focus their attention on our behavior and not on moral action itself which entails agency, they omit the important distinction between having the inclination toward something and the process of espousing and justifying one's beliefs. In search of a satisfactory image which could elucidate the significance of this distinction, let me invoke Frankfurt's concept of double-leveled consciousness (Frankfurt 1971, 5-20). His distinction between "first-order desires" and "second-order desires" allows us not only to reflect on the groundings of our beliefs, choices, policies, and sorts of motives, but in the first place it addresses the question of the essential features of consciousness, namely of intentionality and selfawareness. These in turn point to the active aspect of our nature, which is moral agency. That is not, of course, to suggest that those who oppose the idea of moral bioenhancement disregard the contribution of deterministic factors. These are indeed taken into account, but that does not mean that they determine the act of choosing itself. For instance, Habermas applies a nondeterministic concept of conditioned freedom, he argues that "the conditioned character of my decision does not bother me as long as I can understand this "occurrence" retrospectively as an unfolding process of reflection (however implicit) in which I take part as a participant in discourse or as a subject reflecting in foro interno. For in that case I make the decision based on my own understanding" (Habermas 2008, 158). What is claimed here is that we humans possess certain capacities that other creatures do not, the most significant of these being self-awareness-a particular approach towards ourselves, the possibility of us distancing ourselves as moral agents from the deterministic factors of our "first nature". That is why McDowell may say:

In imparting logos, moral education enables one to step back from any motivational impulse one finds oneself subject to, and

${ }^{10}$ I am grateful to Professor Robert Piłat for reminding me of this important point. He discusses it thoroughly in Refleksja i kompetencja moralna and O kruchości refleksji. (see: Piłat 2013, 169-188, 15-24; also Korsgaard 1989). 
question its rational credentials. Thus it affects a kind of distancing of the agent from the practical tendencies that are part of what we might call his first nature. Nature controls the behaviour of a non-rational animal. It seemed that reason compels nature to abdicate that authority, leaving a void that selfinterest seemed fitted to fill (McDowell 2002, 188).

This very possibility of us distancing ourselves points to the capacity for "evaluating" which is a reflective kind. This is the idea Frankfurt calls "reflective-self-evaluation" which manifests in the formation of second-order desires.

3. Transhumanists adopt a different approach to virtue. They do not think of it in terms of its teleological sense (hexis proairetiké), but they define it usually in psychological terms as a state of mind created by various kinds of emotions. Such an attitude fails to explain the reasons for holding certain beliefs according to which one decides to act. What is left out in the idea of moral enhancement is that virtuous action results in the first place from our recognition and acknowledgement of norms and values rather than from our habits. But, of course, the recognition of norms does not determine action. There are many reasons for this; some of them have to do with a problem that has been understood since the ancients, namely the problem of akrasia or weakness of the will, which naturalistic interpretation mistakenly explains by appealing to the idea of lacking moral fibre or having poor "moral dispositions".

The proponents of moral bioenhancement may tell us about the inclinations and neurologically observable processes that influence our behavior, but they cannot provide us with an explanation of the normative character of our decisions and reasons from which an agent performs the action, why I commit myself to act in the way I choose to act. One cannot derive the source of self-imposed obligation simply from natural causality (see: Piłat 2013, 170). In this sense I argue that the reductionist programme underlying the idea of moral transhumanism is limited in principle. The idea of moral enhancement rests on certain assumptions that pertain to understanding the moral nature of action. Transhumanists believe that biomedical interventions might result in having "morally better motives." The arguments which they espouse in support of this claim rely on consequentialist considerations. Since they focus on results and effectiveness of action, they dismiss the normative relation between the moral agent and the aim of action (see: Piłat 2013,177). 


\title{
3. Autonomy and Aiming toward Moral Perfection
}

\begin{abstract}
Does it really matter whether we act as our humanity requires, whether we find some ways of identifying ourselves and stand by them? But in this case you have no option but to say yes. Since you are human you must take something to be normative, that is, some conception of practical identity must be normative for you. If you had no normative conception of your identity, you could have no reasons for action, and because your consciousness is reflective, you could then not act at all (Korsgard 2003,123).
\end{abstract}

One is not simply a moral agent and nothing more, but without being a moral agent we would deny our humanity. This view demonstrated by Korsgaard has two important implications. Firstly, one's relation towards values is constitutive of one's practical identity. Secondly, and relatedly, the consequences of our actions not only impact the world, but also ourselves: the way we chose to act according to our "second order volitions" actually constitutes the one who acts. The Nietzschean term "value" contains the idea that our "values" are our creations. Similarly, the ancients believed that morality is not something that may be "injected" into us from the outside, but that it can only be attained by acting morally. In The Human Condition Hannah Arendt writes that "in acting and speaking we show who we are, we reveal actively our unique personal identities and thus make our appearance in the human world, while our physical identities appear without any activity of our own in the unique shape of the body and sound of the voice" (Arendt 1998, 179).

In discussing the problem of the transhumanistic approach to values and moral insight, I claimed that it consists mainly in focusing on the passive aspect of human nature. The point is that we understand ourselves not only as subjects of experiences, but in the first place as autonomous agents. A significant account of personal autonomy has been given by Habermas (see: Habermas 2003). This concept has laid the basis of the central premise in his arguments against the transhumanistic stance. Morality cannot do without one's autonomous approach to norms and values. "Capacity for reflective selfevaluation" means that we can shape ourselves through this evaluation. Furthermore, this evaluation entails responsibility. Charles Taylor emphasizes that it is this kind of evaluation which one may regard to be essential to the notion of the self. The term "evaluate" implies that this is something we do, that our evaluations emerge from our activity of evaluating, and in this sense are our responsibility (Taylor 1976, 289).

Moral development requires self-understanding, acting subjects who directs their own intentions and attributes responsible authorship for their actions to themselves. All this happens in the space between knowing the good and doing the good. And of this particular space Harris says that it is a region 
entirely inhabited by freedom (Harris 2011, 104). Freedom is the condition sine qua non of the realization of our own action, which in turn allows us to create our practical identity. These two points are inextricably related. The autonomy of one's relation towards values is crucial to the self-understanding subject. This is not, of course, to suggest that what is involved here is an idealistic conception of freedom of action. We are not situated outside the world, therefore there is no point in holding a concept of freedom that entails being cut off from all empirical contexts. Yet, this proposed conception of freedom of action is nevertheless a strong one, for freedom here is linked with the concept of the rational explanation of action. I believe one finds this sort of argument in Habermas' claim that the motivating power of reasons for action presupposes that under certain conditions they are "decisive" for the one who acts, that is, they are sufficient to "bind" the agent's will. Motivation by reasons requires not merely a rational, position-taking agent for whom reasons count, but one who lets herself be determined by her judgment (Habermas 2008, 160). This important conviction is precisely what I mean when I state that the problem of moral enhancement must bring us back to the concept of autonomy of will and of the self-determining agent. It is those issues that continue to drive me towards the ancient idea of moral excellence, in particular to Aristotle's theory of virtue.

As the above demonstrated concept of a self-determining, acting subject reveals, there can be no doubt that biomedical forms of moral enhancement are to be regarded as controversial. First, the very idea of aiming toward moral perfection requires active agency, and since the proponents of transhumanism concentrate on the passive aspect of our nature, they end up embracing a reductionist view of morality. Striving for moral excellence should stem from one's own decisions, otherwise we risk the possibility of "self-alienation" - of losing, confounding, and abandoning our identity (see: President's Council on Bioethics 2003, 294). The forms of moral improvement ought to be adjusted to our grasp of ourselves-to us as self-understanding, acting subjects. What we may say with confidence is that ethical improvement requires time and experience. It is not only the end toward which one strives that truly counts; the very path that leads to this end also has significant impact on the one who took it. Let us support this with Aristotle, who argues that:

Moral virtue comes about as a result of habit, whence also its name (ethike) is one that is formed by a slight variation from the word ethos (habit). From this it is also plain that none of the moral virtues arises in us by nature ... the virtues we get by first exercising them ... we become just by doing just acts, temperate by doing temperate acts, brave by doing brave acts (Aristotle 2009, 23). 
In other words, the manner in which one acquires and implements moral virtue decides about the "merit" that "constitutes one of the most significant determining factors in the axiological structure of man" (Stróżewski 2013, 265). This I believe shall never be a matter of biomedical enhancement proposed by the new science of behavioural control. The idea of neuro-enhancement that pertains to physical ability enhancement, cognitive enhancement (intelligence, memory) and natural lifespan enhancement may point to the question of becoming "better" human beings, but has nothing to do with the question of becoming a better person and improving one's merit.

\section{Concluding Remarks}

The arguments presented in this article are far from exhausting the question of what is wrong with the idea of moral enhancement. I tried to demonstrate that the moral stakes in the enhancement debate are not fully captured if one focuses mainly on calculating the costs and benefits of the enhancement. Nor can we grasp them when we ask whether a programme could be offered of using knowledge from "the science of morality" to deliberately and effectively improve moral dispositions and behavior (Savulescu \& Persson 2012). What is truly in question here is the condition of possibility of moral agency itself on the one hand, and the complex character of moral decision making on the other. In considering moral agency I claimed that it entails autonomy, which in turn involves rationality and freedom of the will. The idea of moral enhancement simply points to results and the effectiveness of action. But it fails to address the issue of the normative relation between the moral agent and the aim of action.

At the end let me invoke Harris' objection to moral bioenhancement which originates from Milton (Book III of Paradise Lost). If there is freedom of the will, there has to be the risk of fall.

When God says of man that 'he had of me all he could have' he qualifies this in two ways. Firstly by the vainglorious claim 'I made him just and right', and second by a wonderful analysis of freedom: 'sufficient to have stood, though free to fall'. Milton's God was certainly overestimating her role in making humankind just, right and all the rest, but nature, or more particularly, evolution, has done most of this for us. We have certainly evolved to have a vigorous sense of justice and right, that is, with a virtuous sense of morality. God was, of course, speaking of the fall from Grace when congratulating herself on making man 'sufficient to have stood though free to fall'; she was underlining the sort of existential freedom ... which allows us the exhilaration and joy of choosing (and changing at will) our own path through life. And while we are free to allow others to do this for us and to be tempted and to fall, or be bullied, persuaded or cajoled into falling, we have the wherewithal to stand if we choose. So that 
when Milton has God say mankind 'had of me all he could have', he is pointing out that while his God could have made falling impossible for us, even God could not have done so and left us free. Autonomy surely requires not only the possibility of falling but the freedom to choose to fall, and that same autonomy gives us self-sufficiency; 'sufficient to have stood though free to fall (Harris 2011, 103).

\section{References}

Arendt, H. 1998. The Human Condition. Chicago - London: University of Chicago Press.

Aristotle, 2009. The Nicomachean Ethics. Trans. D. Ross. New York: Oxford University Press.

Daniels, N. 2013. "Can Anyone Really Be Talking about Ethically Modifying Human Nature." In J. Savulescu \& N. Bostrom (eds.), Human Enhancement. Oxford: Oxford University Press: 26-42.

Douglas, T. 2008. "Moral Enhancement." Journal of Applied Philosophy 25(3): 228-245.

Frankfurt, H. G. 1971. "Freedom of Will and Concept of a Person." The Journal of Philosophy 68(1): 5-20.

Grimaldi, W. M. A. 1972. Studies in the Philosophy of Aristotle's Rhetoric (Hermes Einzelschriften). Wiesbaden: Franz Steiner.

Haack, S. 2014. "Brave New World: On Nature, Culture and the Limits of Reductionism." Invited lecture at a conference Science is All We Need? Abraham Kuyper Centre, Free University of Amsterdam.

Habermas, J. 2003. The Future of Human Nature. Cambridge: Polity Press.

-_- 2008. Between Naturalism and Religion. Philosophical Essays. Cambridge: Polity Press.

Harris, J. 2011. "Moral Enhancement and Freedom". Bioethics 25(2): 102-111.

Kant, I. 1993. Grounding for the Metaphysics of Morals: With on a Supposed Right to Lie Because of Philanthropic Concerns. Trans. J. W. Ellington, Indianapolis - Cambridge: Hackett Publishing.

Korsgaard, Ch. M. 1989. "Personal Identity and the Unity of Agency: A Kantian Response to Parfit." Philosophy and Public Affairs 18(2): 101-132.

-_- 2008. The Constitution of Agency. Essays on Practical Reason and Moral Psychology. Oxford, Oxford University Press.

Korsgaard, Ch. M., Cohen, G. A. et al. 2003. The Sources of Normativity. Cambridge Mass: Cambridge University Press.

Lewandowski, W. 2013. „Genetyczne udoskonalanie a moralna doskonałość". Etyka 47: 67-83. 
McDowell, J. 1996. Mind and World: With a New Introduction. Cambridge: Harvard University Press.

McDowell, J. 2001. Mind, Values and Reality. Cambridge: Harvard University Press.

Persson, I. \& Savulescu, J. 2008. "The Perils of Cognitive Enhancement and the Urgent Imperative to Enhance the Moral Character of Humanity." Journal of Applied Philosophy 25(3): 162-177.

- - . 2012. Unfit for the Future: The Need for Moral Enhancement. Oxford: Oxford University Press.

Piłat, R. 2013. Powinność i samowiedza. Studia z filozofii praktycznej. Warszawa: Cardinal Stefan Wyszyński University Press.

President's Council on Bioethics 2003. Beyond Therapy: Biotechnology and the Pursuit of Happiness. New York: Regan Books.

Sandel, M. 2007. The Case Against Perfection. Ethics in the Age of Genetic Engineering. Cambridge, Mass. - London: Harvard University Press.

Savulescu, J. \& Kahane, G. 2009. "The Moral Obligation to Create Children with the Best Chance of the Best Life." Bioethics 23(5): 274-290.

Savulescu, J. \& Persson, I. 2012. "Moral Enhancement, Freedom and the God Machine." The Monist 95(3): 399-421.

Soniewicka, M. 2015. „Biologiczne podstawy moralności w kontekście genetycznego ulepszania człowieka". In J. Stelmach, B. Brożek, \& K. Eliasz (eds.), Naturalizacja prawa: interpretacje. Warszawa: Wolters Kluwer: 279-298.

Stróżewski, W. 2013. Existence, Sense and Values. In S. T. Kołodziejczyk (ed.), Essays in Metaphysics and Phenomenology. Frankfurt am Main: Peter Lang Edition.

Taylor, Ch. 1976. "Responsibility for Self." In A. Oksenberg Rorty (ed.), The Identities of Persons. Berkeley, London: University of California Press: 281-300.

-—- 1985. Human Agency and Language. Philosophical Papers I. Cambridge: Cambridge University Press.

- - . 1994. Sources of the Self. The Making of the Modern Identity. Cambridge: Harvard University Press.

Walker, M. 2009. "Enhancing Genetic Virtue. A Project for Twenty-First Century Humanity?." Politics and the Life Sciences 2(28): 27-47.

Williams, B. 1996. Morality: An Introduction to Ethics. Cambridge: Cambridge University Press.

———. 2006. Ethics and the Limits of Philosophy. London: Routledge. 


\title{
Adriana Warmbier (Cracow)
}

\section{Moral Perfection and the Demand for Human Enhancement}

\begin{abstract}
In this article I discuss one of the most significant areas of bioethical interest, which is the problem of moral enhancement. Since I claim that the crucial issue in the current debate on human bioenhancement is the problem of agency, I bring out and examine the conditions of possibility of selfunderstanding, acting subjects attributing responsible authorship for their actions to themselves. I shall argue that the very idea of moral enhancement, properly understood, fails to justify the claims that enhancing the "biological" factor that plays a part in the process of making moral choices, whether through biomedical or genetic interventions, will actually increase the probability of having "morally better future motives".
\end{abstract}

Keywords. Human enhancement, moral enhancement, human agency, free will, freedom, autonomy, normativity

Ethics in Progress (ISSN 2084-9257). Vol. 6 (2015). No. 1. pp. 23-37.

doi:10.14746/eip.2015.1.4 